\title{
SMALL AND MEDIUM SIZED LIQUID METAL COOLED SAFETY ANALYSIS USING MULTI LEVEL COMPLEXITY MODEL
}

\author{
ZAKI SU'UD \\ Nuclear Research Group, Dept. of Physics ITB, \\ Jl. Ganesha 10, Bandung 40132, Telp.022-253-4094, Fax 022-250-6452 \\ Email : szaki@,fi.itb.ac.id
}

\begin{abstract}
SMALL AND MEDIUM SIZED LIQUID METAL COOLED SAFETY ANALYSIS USING MULTI LEVEL COMPLEXITY MODEL Inherent safety characteristics of liquid metal cooled fast reactors is very important capital for next generation nuclear power plants. However inherent safety assessment need appropriate computer code or experiment. Here, a computer code for liquid metal cooled fast reactor accident analysis with various level of complexity has been developed. At the simplest approach, quasi-static method is adopted to get asymptotic condition during UTOP, ULOF, and UTOP-ULOF accident. Here we can get asymptotic power level, asymptotic average coolant temperature, and asymptotic fuel temperature for a certain external reactivity and natural circulation level. In the next grade, the code will simulate transient effect using point kinetic method and quasistatic approach for thermal hidraulic analysis. Here we can get time depedent power change, coolant temperature change and fuel temperature change. Finally in the rigorous analysis, coupled space dependent kinetic and transient thermal hydraulic are coupled and solved to get time depedent information of various process involved in the accident.
\end{abstract}

Keywords : Accident, ULOF, UTOP, reactivity, feedback, quasistatic, space-depedent kinetic.

\begin{abstract}
Abstrak
ANALISIS KESELAMATAN REAKTOR BERPENDINGIN LOGAM CAIR UKURAN KECIL DAN MENENGAH MENGGUNAKAN MODEL KOMPLEKSITAS MULTI

LEVEL. Karakteristik keselamatan inheren dari reaktor cepat berpendingin logam cair merupakan modal yang sangat penting bagi pembangkit listrik nuklir generasi mendatang. Namun, penilaian keselamatan inheren membutuhkan kode komputer atau eksperimen yang sesuai. Di sini, kode computer untuk analisis kecelakaan reactor cepat berpendingin logam cair dengan berbagai tingkat kompleksitas telah dikembangkan. Pada pendekatan yang paling sederhana, metode quasi-statis diterapkan untuk memperoleh kondisi asimptotik selama kecelakaan UTOP, ULOF, dan UTOP-ULOF. Kita bisa mendapatkan tingkat tenaga asimptotik, suhu pendingin rata-rata asimptotik, dan suhu bahan baker asimptotik untuk tingkat sirkulasi alami dan reaktivitas eksternal tertentu. Pada tahap berikutnya, kode tersebut akan mensimulasi efek transien menggunakan metode point-kinetik dan pendekatan quasistatik untuk analisis hidraulik thermal. Kita bisa memperoleh perubahan daya tergantung waktu, perubahan suhu pendingin, dan perubahan suhu bahan baker. Akhirnya, dengan analisis yang teliti, kinetic tergantung ruang berpasangan dan hidrolik thermal transien dipasangkan dan diselesaikan untuk mendapat informasi tergantung-waktu dari berbagai proses yang terlibat dalam kecelakaan tersebut.
\end{abstract}

Kata kunci : Kecelakaan, ULOF, UTOP, reaktivitas, umpan balik, quasistatic, space-depedent kinetic. 


\section{INTRODUCTION}

TMI-2 and Chernobyl accidents have pushed the safety paradigm of nuclear reactors toward inherent/passive safety. For liquid metal cooled fast reactors, proper combination of reactivity feedback will results in inherent safety capability against unprotected rod run out transient over power (UTOP) accident and unprotected loss of flow (ULOF) accident (Su'ud and Sekimoto, 1995; Su'ud and Sekimoto, 1996; Su'ud, 1998; Su'ud, 2003; Su'ud, 2004a; Su'ud, 2004b; Su'ud, 2004c; Su'ud, 2004).

During unprotected rod runout transient over power (UTOP) accident, reactor power increases due to external reactivity causing the increase of coolant and fuel temperature which induce overall negative reactivity feedback from doppler, radial expansion, axial fuel expansion and coolant density effect. The asymptotic equilibrium condition occurs when the negative reactivity feedback completely compensates external possitive reactivity(Su'ud and Sekimoto, 1996; Su'ud, 2004).

In case of unprotected loss of flow (ULOF) accident, the loss of pumping power causes decrease of coolant flowrate. In the short term it causes the increase of coolant temperature but the decrease of fuel-coolant temperature difference. In asymptotic equilibrium condition, the negative reactivity due to the increase of coolant temperature is compensated by possitive reactivity due to fuel temperature decrease in reduced power condition (Su'ud and Sekimoto, 1996; Su'ud, 2004).

Therefore UTOP and ULOF accident have difference inherent defence mechanism and optimal characteristics are needed to survive both UTOP and ULOF accidents. In conventional LWR and MOX based liquid metal cooled fast reactors the temperature difference between fuel pin outer surface and pin center temperature can reach more than $1500^{\circ} \mathrm{C}$. On the other hand, natural circulation level is very small (less than $10 \%$ of full power). Therefore during ULOF accident severe condition occurs, the decrease of power level to match natural circulation level will cause large positive reactivity due to doppler which can not be compensated safely by coolant temperature increase based negative feedback.

Here for special condition, i.e. relatively low power density and relatively large natural circulation capability (more than $20 \%$ of full power) we can reduce temperature difference between fuel pin outer surface temperature and fuel center temperature. Threfore we found that MOX based $\mathrm{Pb}-\mathrm{Bi}$ cooled fast power reactors can survive ULOF accident inherently.

\section{Quasistatic Model}

In UTOP accident, the positive reactivity drives the power increase, which in turn causes coolant, cladding and fuel temperature increase. The temperature increase draws negative reactivity feedback which compensate the external reactivity. In asymptotic condition the nuclear reactor will be in new stable condition with higher power level.

IN ULOF accident the unbalance between the heat source and the flowrate causes temperature increase in coolant, cladding and fuel which then cause negative 
reactivity feedback. The negative reactivity feedback is then push the power down. At asymptotic condition the nuclear power will be stable in reduced power level.

1. Quasystatic Model Description

The basic model of Quasistatic approach is shown in the following figure

$$
\begin{aligned}
& \text { Outlet }
\end{aligned}
$$

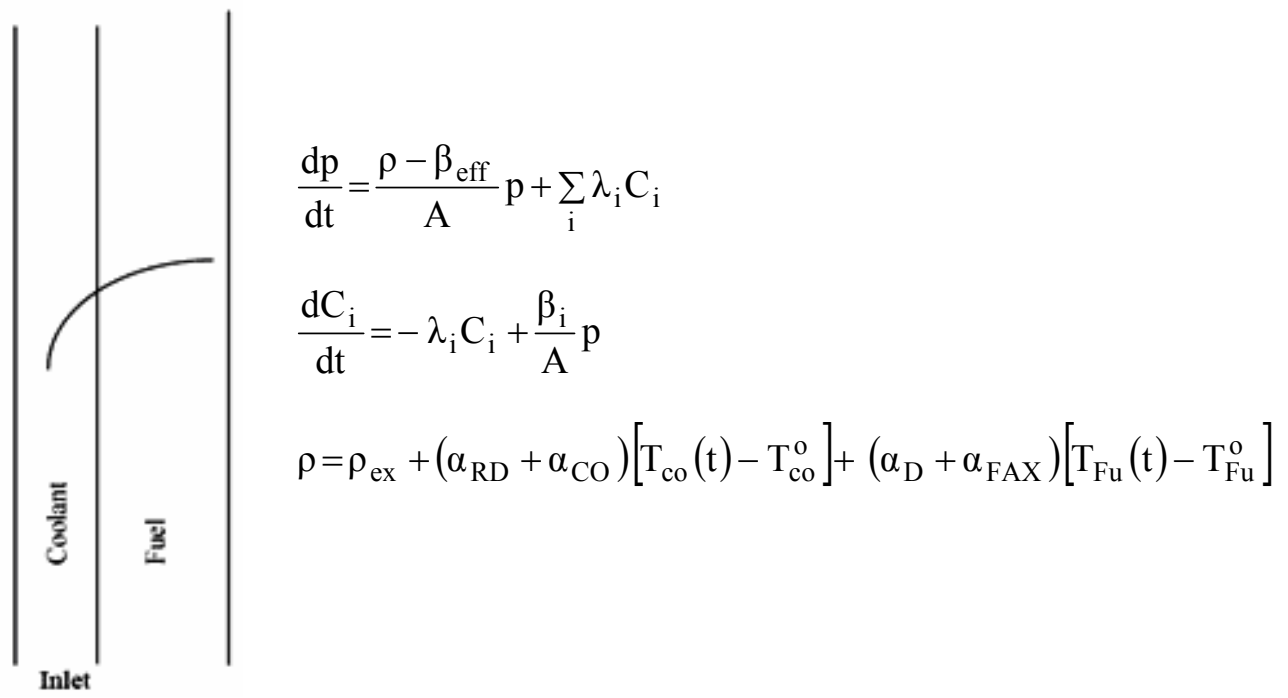

Fig. 1. Quasistatic safety analysis model for liquid metal cooled fast reactors

The coolant average temperature, coolant outlet temperature, coolant-fuel temperature difference, and fuel temperature average are expressed as follows.

$$
\begin{aligned}
& \mathrm{T}_{\text {co,av }}=\frac{\mathrm{T}_{\text {in }}+\mathrm{T}_{\text {out }}}{2} \\
& T_{\text {out }}=T_{\text {in }}+\frac{p P_{o} A_{\text {pin }} H}{f(t) F_{o} C_{p}} \\
& T_{c o, a v}=T_{\text {in }}+\frac{p P_{o} A_{p i n} H}{2 f(t) F_{o} c_{p}} \\
& \Delta T_{c o, f u}=\frac{p P_{o} A_{\text {pin }} H}{k_{f u} 2 \pi R H B}=\frac{p P_{o} A_{p i n}}{2 \pi k_{f u} B}
\end{aligned}
$$




$$
T_{f u, a v}=T_{c o, a v}+\Delta T_{c o, f u}=T_{i n}+\frac{p P_{o} A_{p i n}}{2 \pi k_{f u} B}
$$

where, $f(t)$ is flow rate change with time (relative to initial flow-rate), and $p(t)$ is power change with the time after accident (relative to initial power), and $\mathrm{B}$ is a parameter to adjust the model which in this case was set to 0.8 .

2. Utop-ulof acident simulation using quasistatic model

Using the above description the model for UTOP and ULOF accidents can be described in more detail as follows. At the early stage after accident begin, the power increases due to external positive reactivity, and also the flow-rate decreases due to the coast down of the pumping power. Therefore the coolant and fuel temperature increases due to un-balanced between the heat source and the flow-rate. With the increase of the coolant and fuel temperature then negative feedback occurs and this will continue till this feedback is large enough to compensate external reactivity and to push down the power level to harmonize with the natural circulation level of the flow-rate. At the asymptotic level we will find that the flow rate is in natural circulation level while the power is adjusted to balance the natural circulation level so that the reactor will be in new equilibrium condition. At that time we have.

$$
\begin{aligned}
& \rho=0=\rho_{\mathrm{ex}}+\left(\alpha_{\mathrm{D}}+\alpha_{\mathrm{FAX}}\right)\left[\mathrm{T} \infty(\mathrm{t})-\mathrm{T}_{\infty}^{\mathrm{o}}\right]+\left(\alpha_{\mathrm{D}}+\alpha_{\mathrm{FAX}}\right)\left[\mathrm{T}_{\mathrm{Fu}}(\mathrm{t})-\mathrm{T}_{\mathrm{Fu}}\right] \\
& 0=\rho_{\mathrm{eX}}+\left(\alpha_{\mathrm{D}}+\alpha_{\mathrm{FAX}}+\alpha_{\mathrm{RD}}+\alpha_{\infty}\right)\left[\mathrm{T}_{\infty}(\mathrm{t})-\mathrm{To}_{\infty}^{o}\right]+\left(\alpha_{\mathrm{D}}+\alpha_{\mathrm{FAX}}\right)\left[\Delta \mathrm{T}_{\mathrm{Fu}, \infty}(\mathrm{t})-\Delta \mathrm{T}_{\mathrm{Fu}, \infty} \mathrm{o}\right] \\
& 0=\left(\alpha_{D}+\alpha_{\mathrm{FAX}}+\alpha_{R D}+\alpha_{c o}\right)\left[\frac{p}{f}-1\right] \frac{P_{o} A_{p i n} H}{2 F_{o} C_{p}}+\left(\alpha_{D}+\alpha_{F}\right) \\
& \mathrm{p}\left[\left(\alpha_{\mathrm{D}}+\alpha_{\mathrm{FAX}}+\alpha_{\mathrm{RD}}+\alpha_{\mathrm{co}}\right) \frac{\mathrm{P}_{\mathrm{o}} \mathrm{A}_{\mathrm{pin}} \mathrm{H}}{2 \mathrm{fF}_{\mathrm{o}} \mathrm{C}_{\mathrm{p}}}+\left(\alpha_{\mathrm{D}}+\alpha_{\mathrm{FAX}}\right) \frac{\mathrm{P}_{\mathrm{o}} \mathrm{A}_{\mathrm{pin}}}{\left.2 \pi \mathrm{k}_{\mathrm{Fu}} \mathrm{B}\right]}\right. \\
& =\left(\alpha_{\mathrm{D}}+\alpha_{\mathrm{FAX}}+\alpha_{\mathrm{RD}}+\alpha_{\mathrm{co}}\right) \frac{\mathrm{P}_{\mathrm{o}} \mathrm{A}_{\mathrm{pin}} \mathrm{H}}{2 \mathrm{fF}_{\mathrm{o}} \mathrm{C}_{\mathrm{p}}}+\left(\alpha_{\mathrm{D}}+\alpha_{\mathrm{FAX}}\right) \frac{\mathrm{P}_{\mathrm{o}} \mathrm{A}_{\mathrm{pin}}}{2 \pi \mathrm{k}_{\mathrm{Fu}} \mathrm{B}}
\end{aligned}
$$




$$
p=\frac{\left(\alpha_{D}+\alpha_{F A X}+\alpha_{R D}+\alpha_{c o}\right) \frac{P_{o} A_{\text {pin }} H}{2 f F_{o} C_{p}}+\left(\alpha_{D}+\alpha_{F A X}\right) \frac{P_{o} A_{p i n}}{2 \pi k_{F u} B}-\rho_{e x}}{\left(\alpha_{D}+\alpha_{F A X}+\alpha_{R D}+\alpha_{c o}\right) \frac{P_{o} A_{p i n} H}{2 f F_{o} C_{p}}+\left(\alpha_{D}+\alpha_{F A X}\right) \frac{P_{o} A_{p i n}}{2 \pi k_{F u} B}}
$$

The example of simulation results is shown in the following figure.

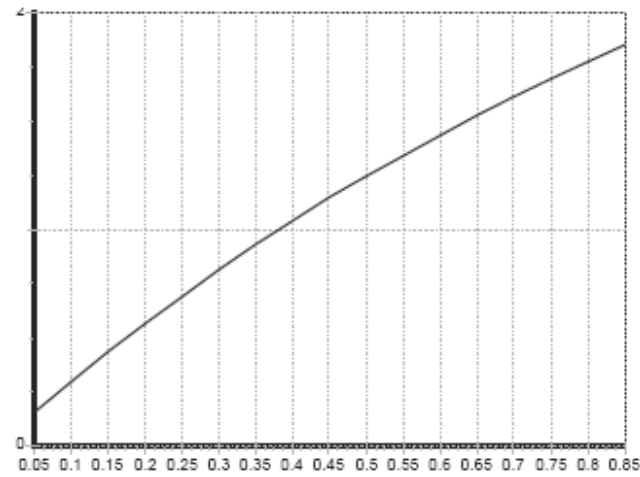

UTOP-ULOF Nitride +0.002

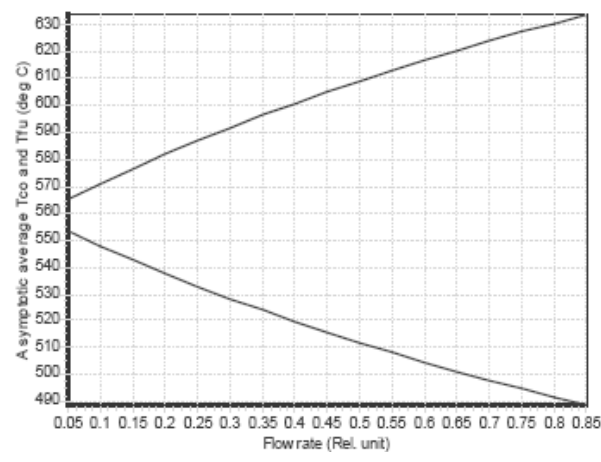

UTOP-ULOF Accident of Nitride Fuelled with $\mathrm{f}=0.2$

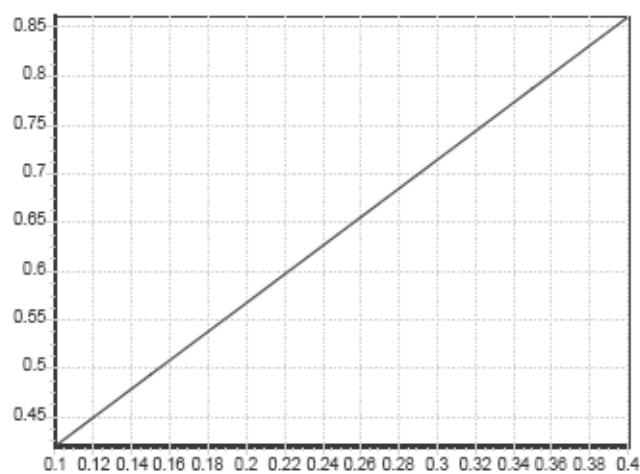

UTOP-ULOF Accident of Nitride Fuelled with $\mathrm{f}=0.2$

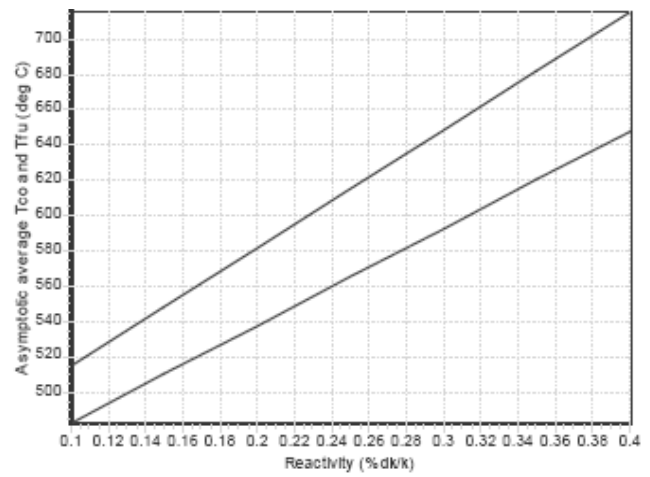

UTOP-ULOF Accident of Nitride Fuelled with $\mathrm{f}=0.2$

Fig. 2. ULOF-UTOP Accident for Nitride Fuelled Core 


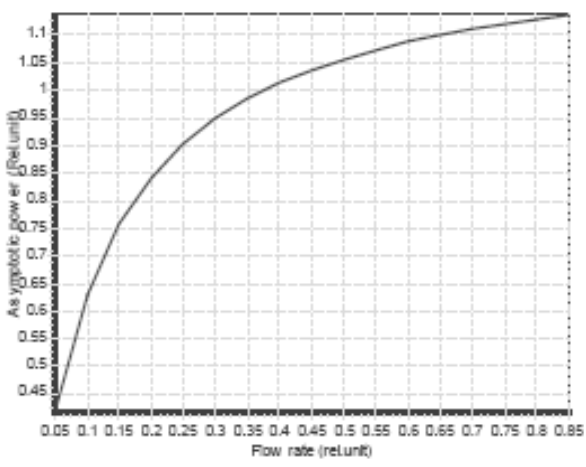

UTOP-ULOF Accident of Nitride Fuelled with $\mathrm{f}$ $=0.2$

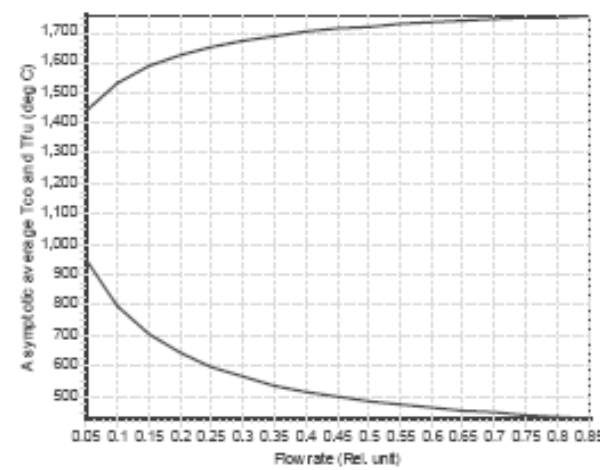

UTOP-ULOF Accident of Nitride Fuelled with $\mathrm{f}$ $=0.2$

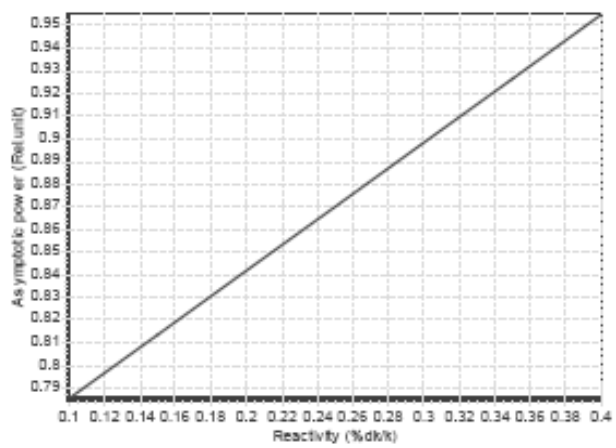

UTOP-ULOF, MOX FUEL with natural Circ Flow 0.2

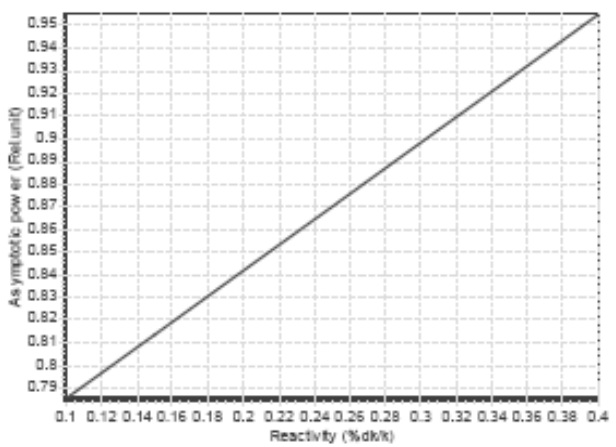

UTOP-ULOF, MOX FUEL

with natural Circ Flow 0.2

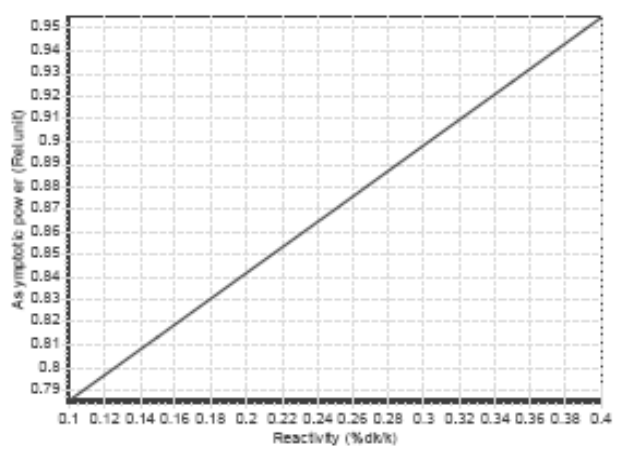

UTOP-ULOF, MOX FUEL with natural Circ Flow 0.2

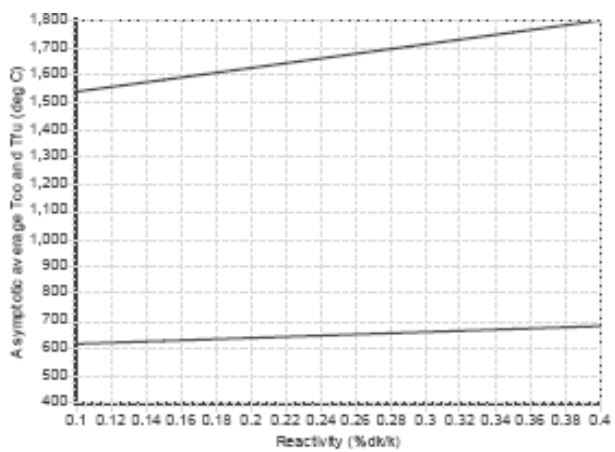

UTOP-ULOF, MOX FUEL with natural Circ Flow 0.2

Fig 3. ULOF-UTOP Accident for MOX Fuelled Core

It is shown that for ULOF-UTOP accident for the same reactivity input for the nitride fuelled and the MOX fueled core. It is clear that the higher the value of 
reactivity the severer the accident and also the higher the natural circulation level is the better the situation. For MOX fuelled core, the natural circulation level is critical, while for nitride fuelled core the reactivity input is ver y critical.

\section{Transient Analysis with Simplified Model}

In this analysis the transient model adopt point kinetic and quasistatic for the thermal hydraulic aspect. The simulation results are shown as follows
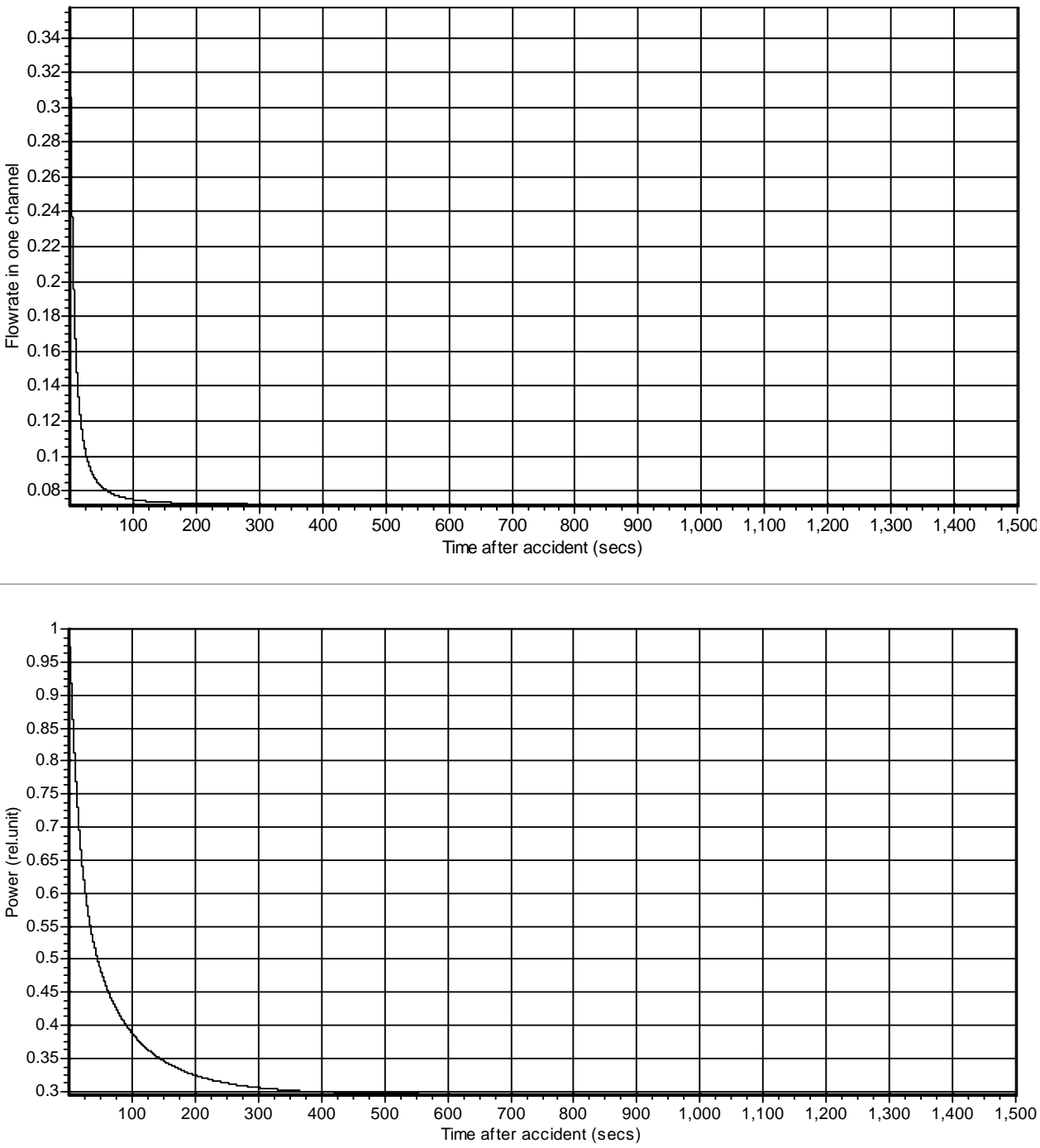

Fig. 4. The Coolant Flow Rate Change During UTOP-ULOF Accident for MOX Fuelled Core 

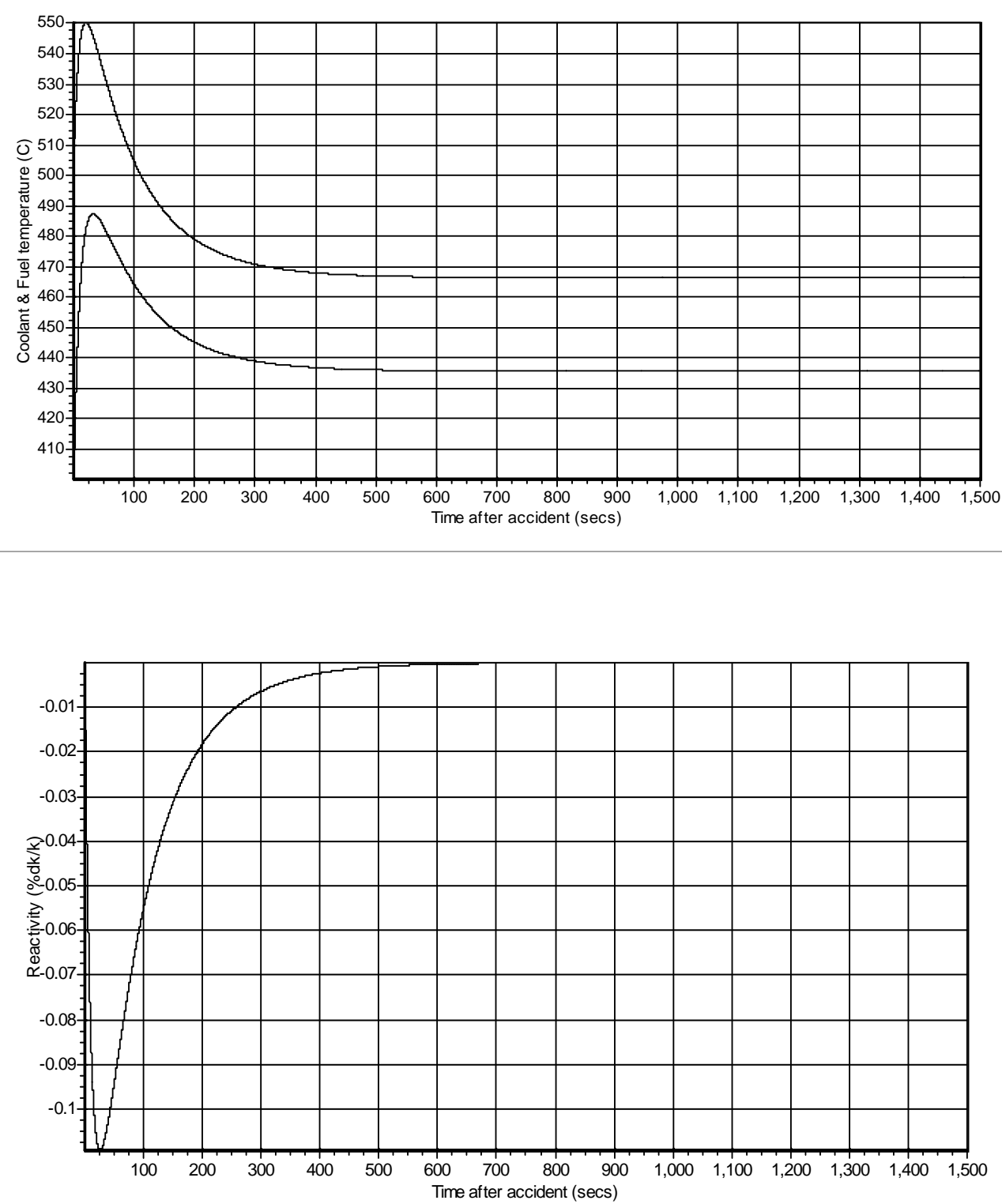

Fig. 4. The Coolant Flow Rate Change During UTOP-ULOF Accident for MOX Fuelled Core (continued) 

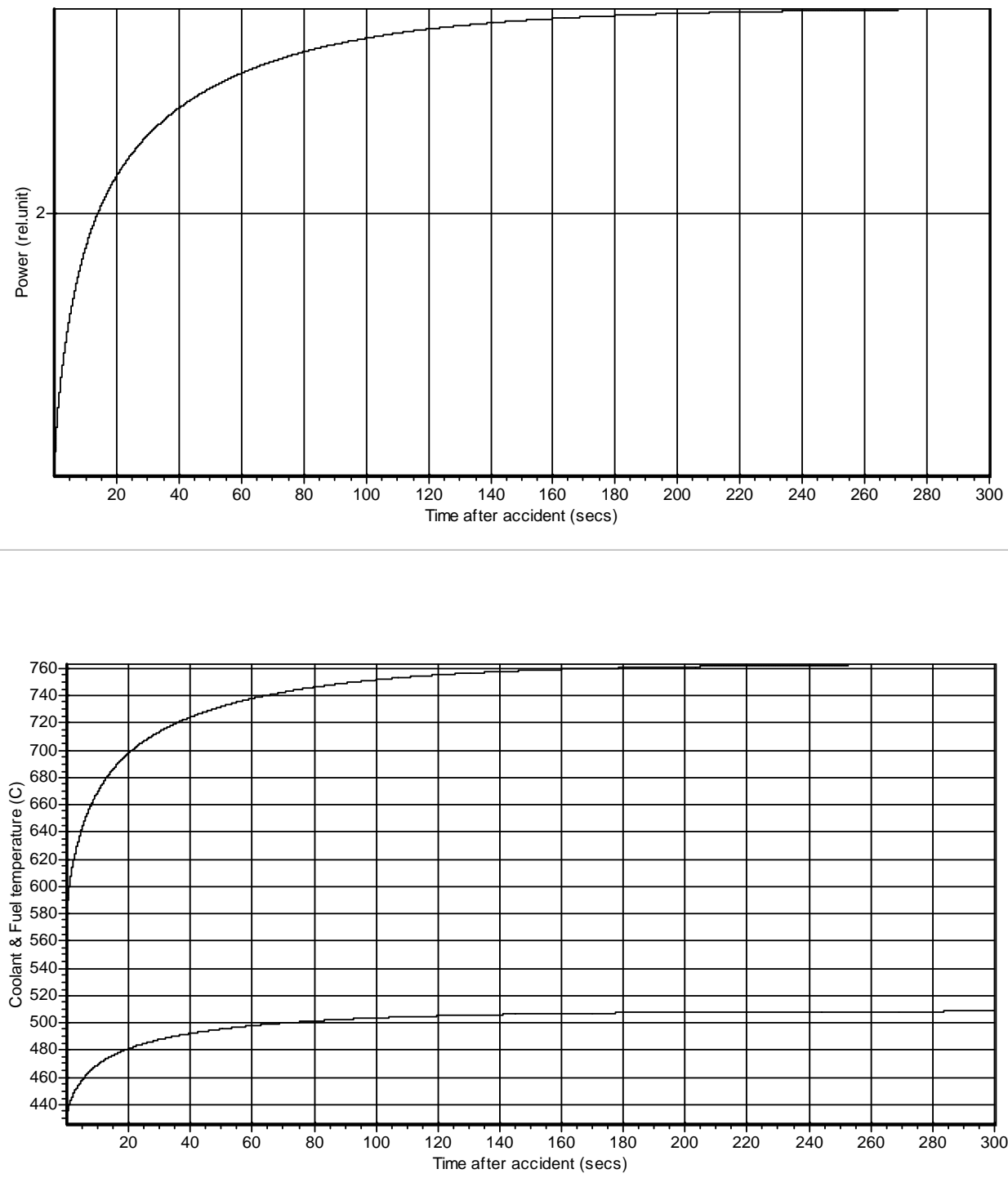

Fig. 4. The Coolant Flow Rate Change During UTOP-ULOF Accident for MOX Fuelled Core (continued) 

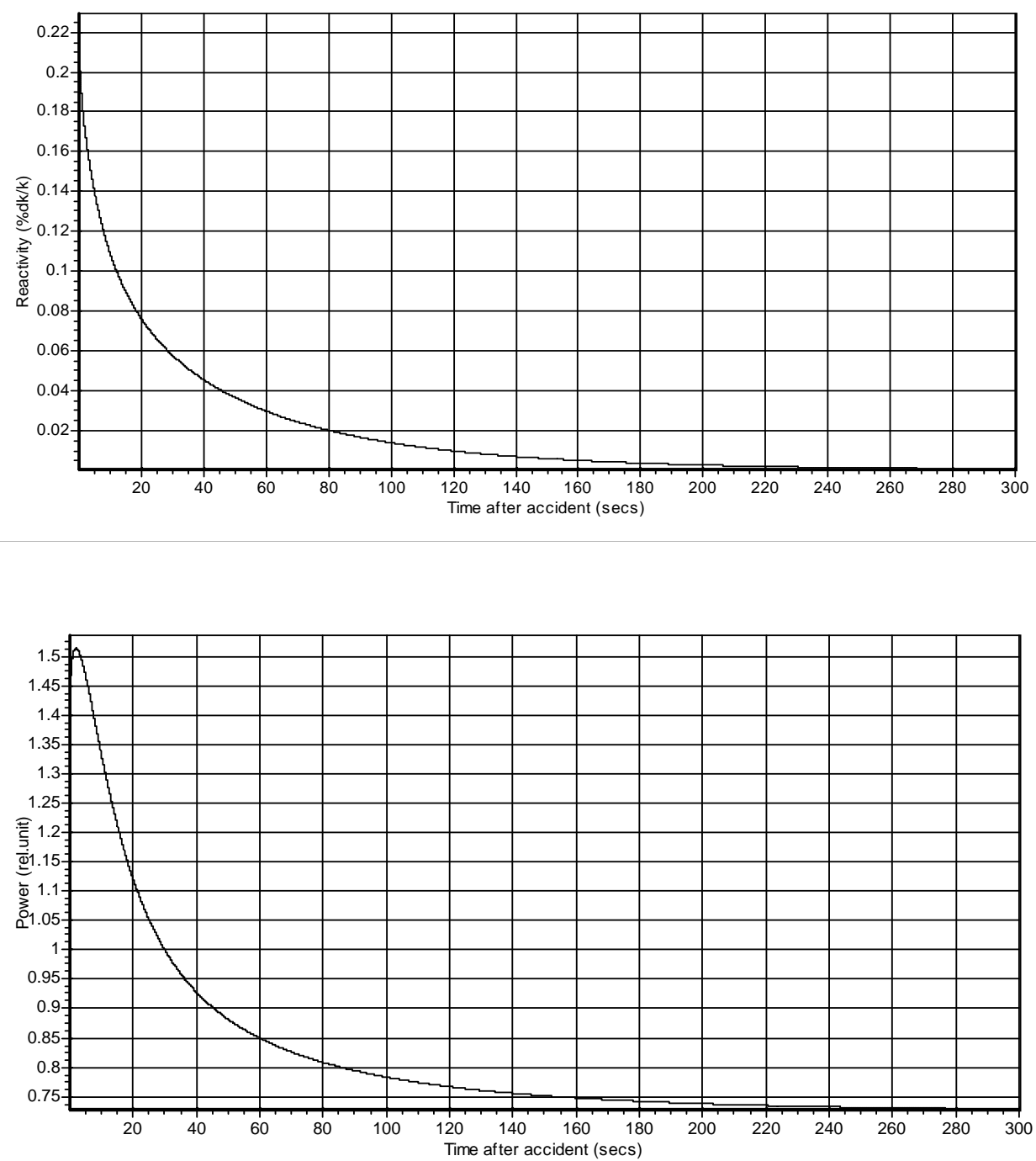

Fig. 4. The Coolant Flow Rate Change During UTOP-ULOF Accident for MOX Fuelled Core (continued) 

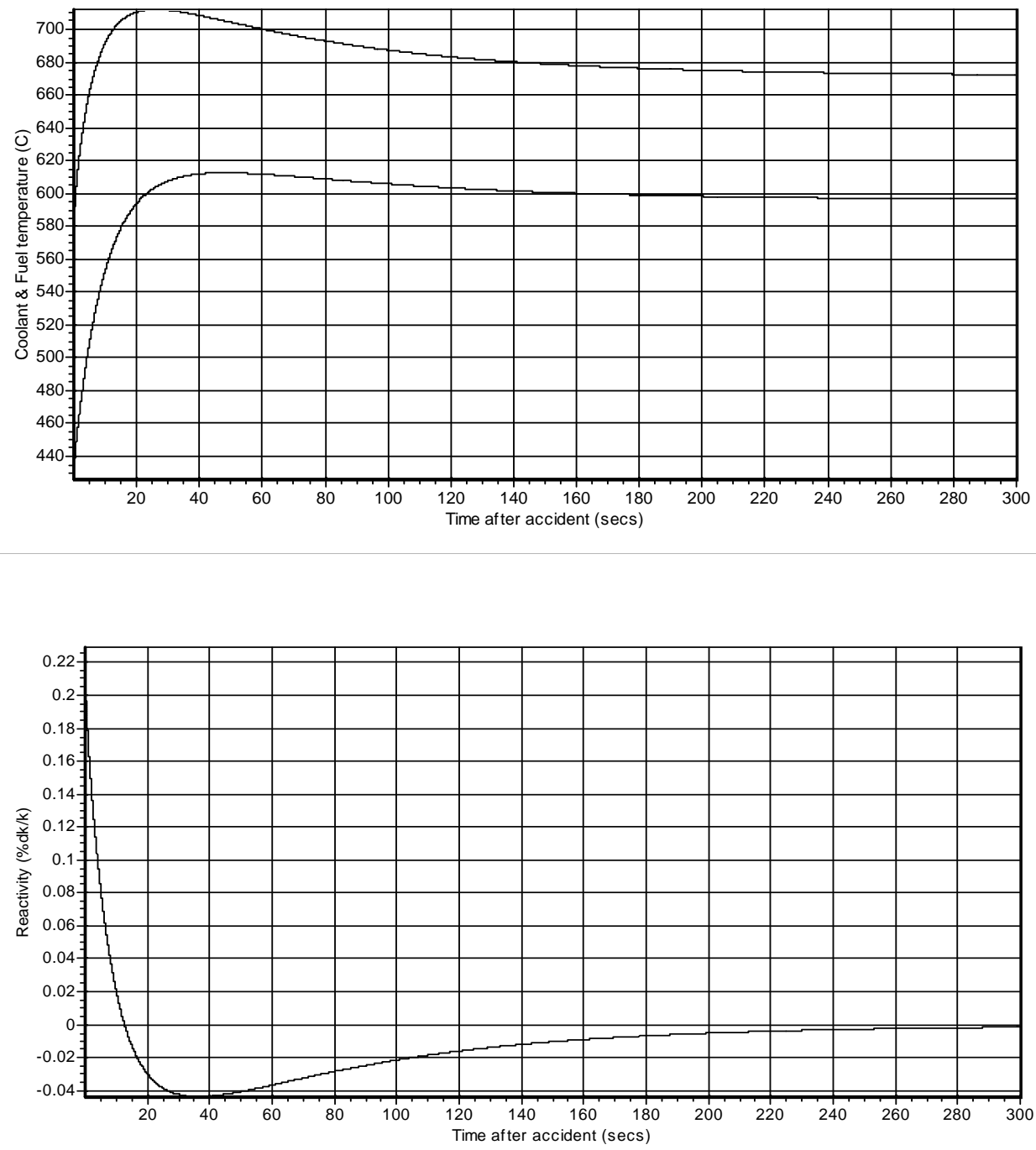

Fig. 4. The Coolant Flow Rate Change During UTOP-ULOF Accident for MOX Fuelled Core (continued) 

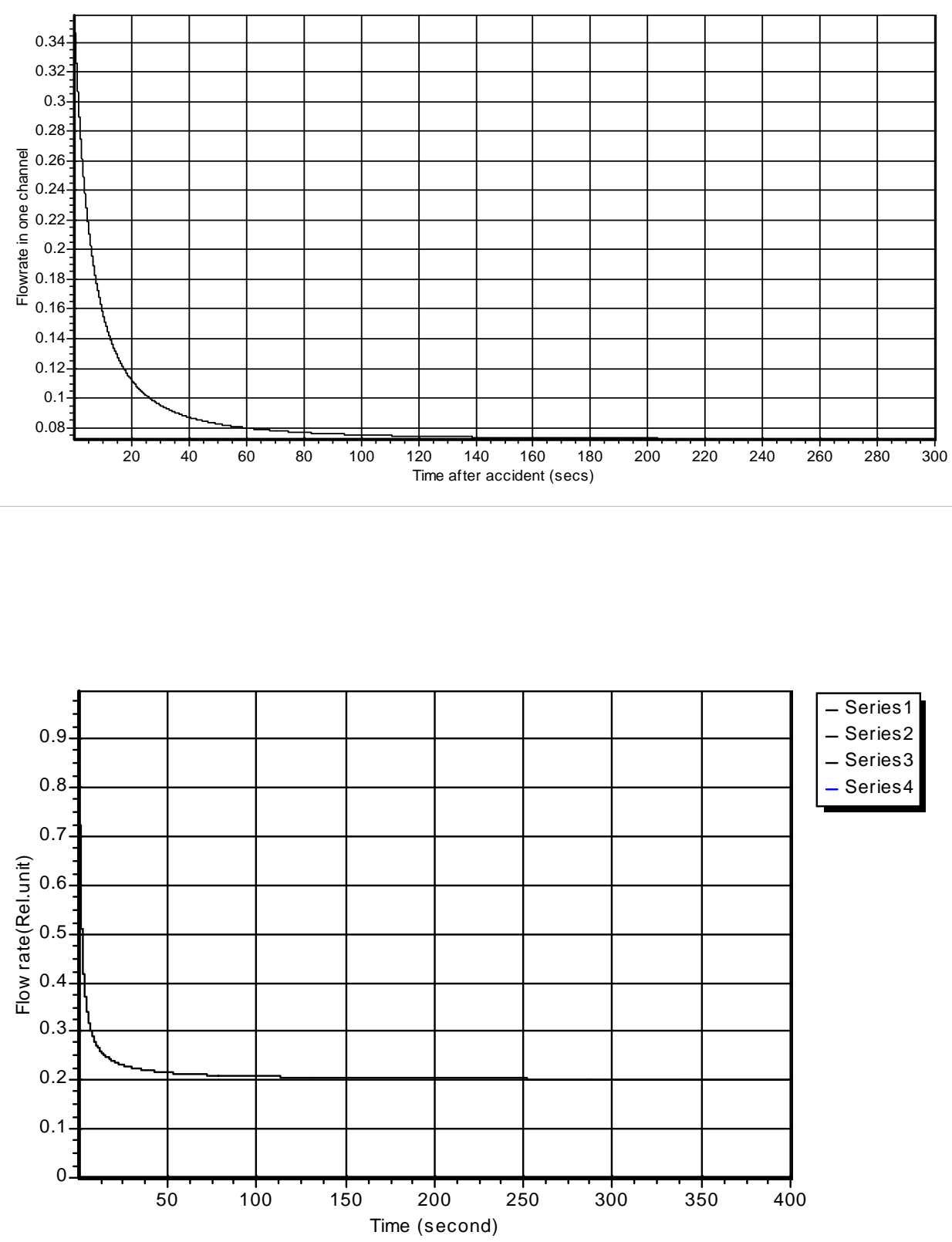

Fig. 4. The Coolant Flow Rate Change During UTOP-ULOF Accident for MOX Fuelled Core (continued) 


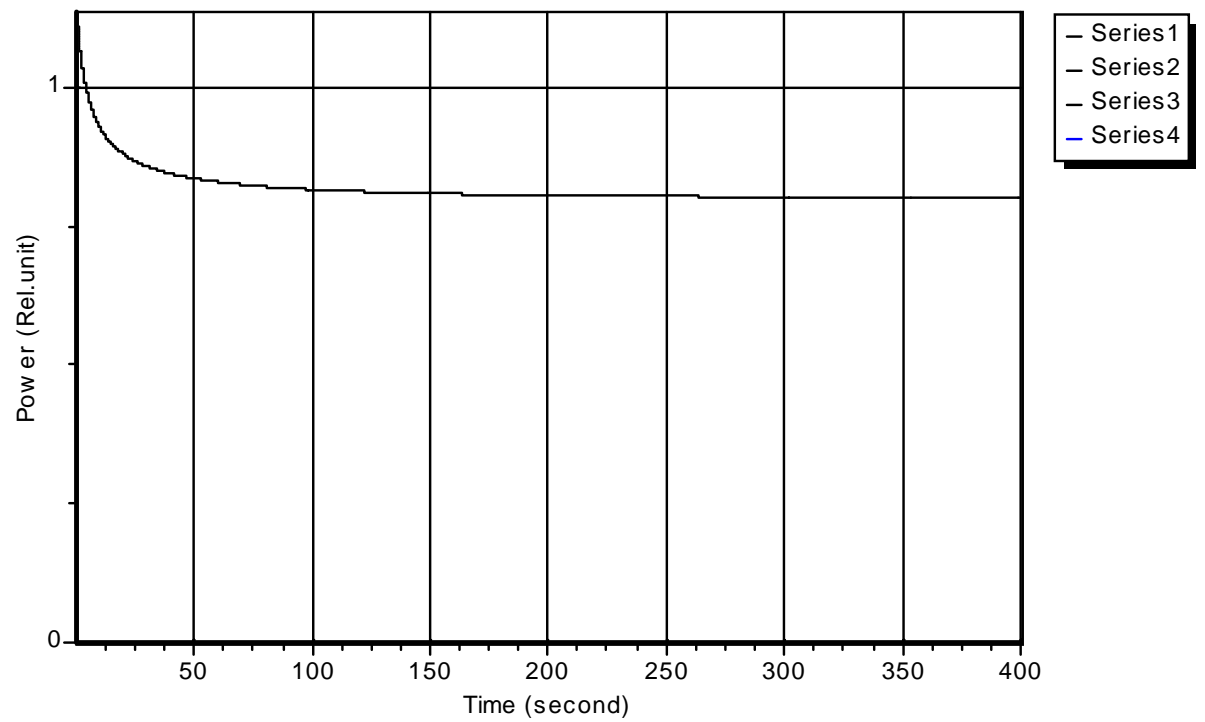

Fig. 5. The Change of Power Level with The Time for ULOF UTOP Accident with MOX Fuelled Core
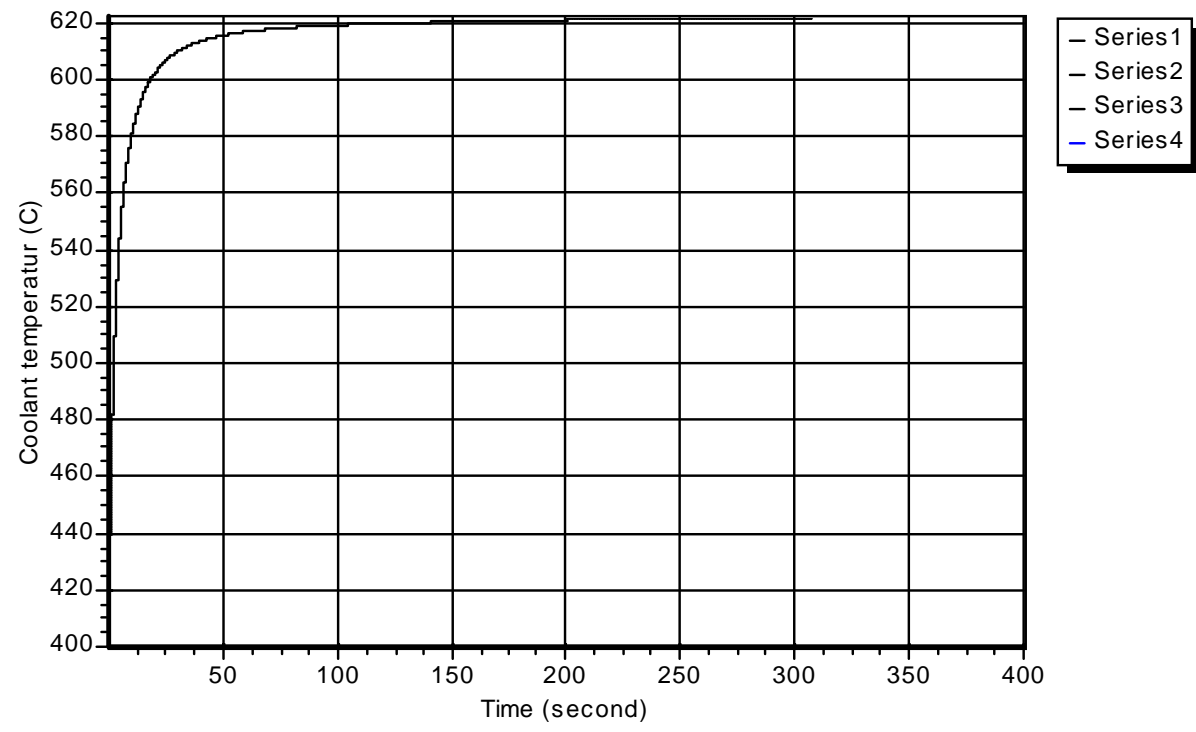

Fig. 6. The Change of Coolant Temperature with The Time for ULOF UTOP Accident with MOX Fuelled Core 


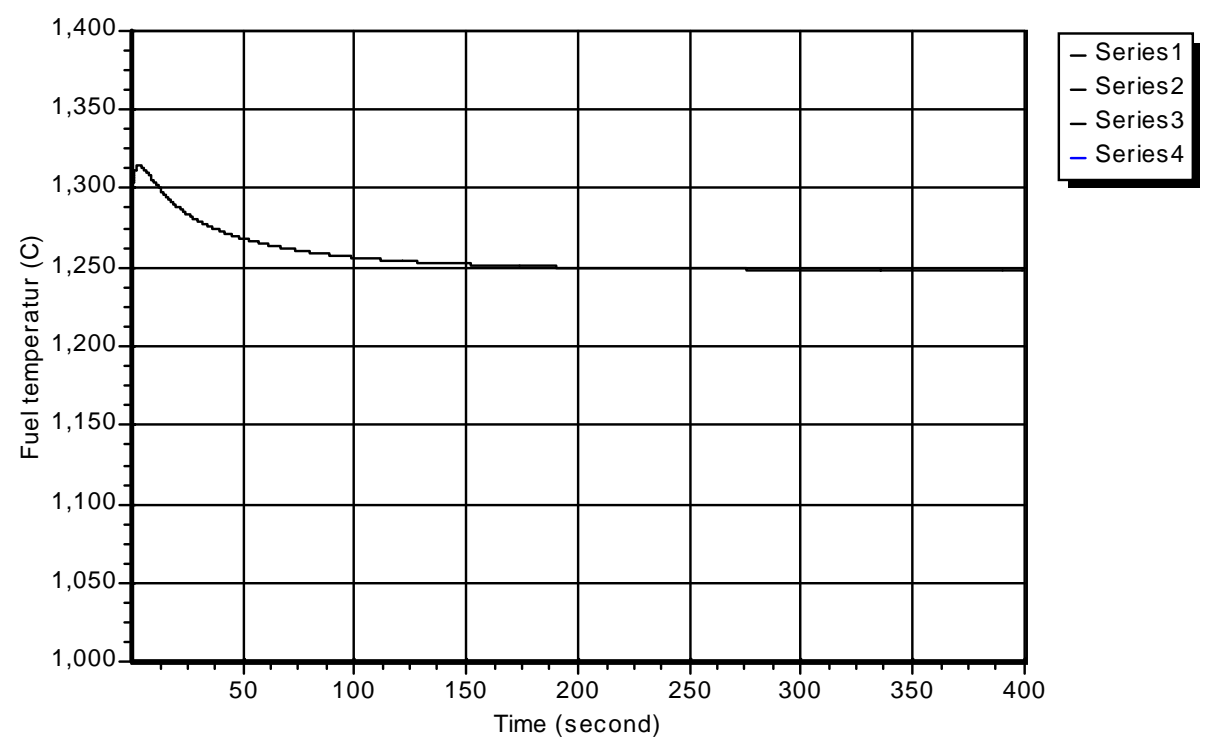

Fig 7. The Change of Fuel Temperature with The Time For ULOF UTOP Accident with MOX Fuelled Core

It is shown that coolant flow rate decreases started at $\mathrm{t}=0$ and go to the natural circulation level. At the same time $0.002 \mathrm{dk} / \mathrm{k}$ excess reactivity entered the core. It causes power and temperature increase as shown in Fig. 5,6 and 7. This simulation was conducted with average power density of $100 \mathrm{~W} / \mathrm{cc}$.

Similar results also obtained for nitride fueled core which simulation results are shown in Figs.8-11. One important difference is that asymptotic power of the core is higher to the MOX fueled core due to its lower thermal conductivity characteristics. 


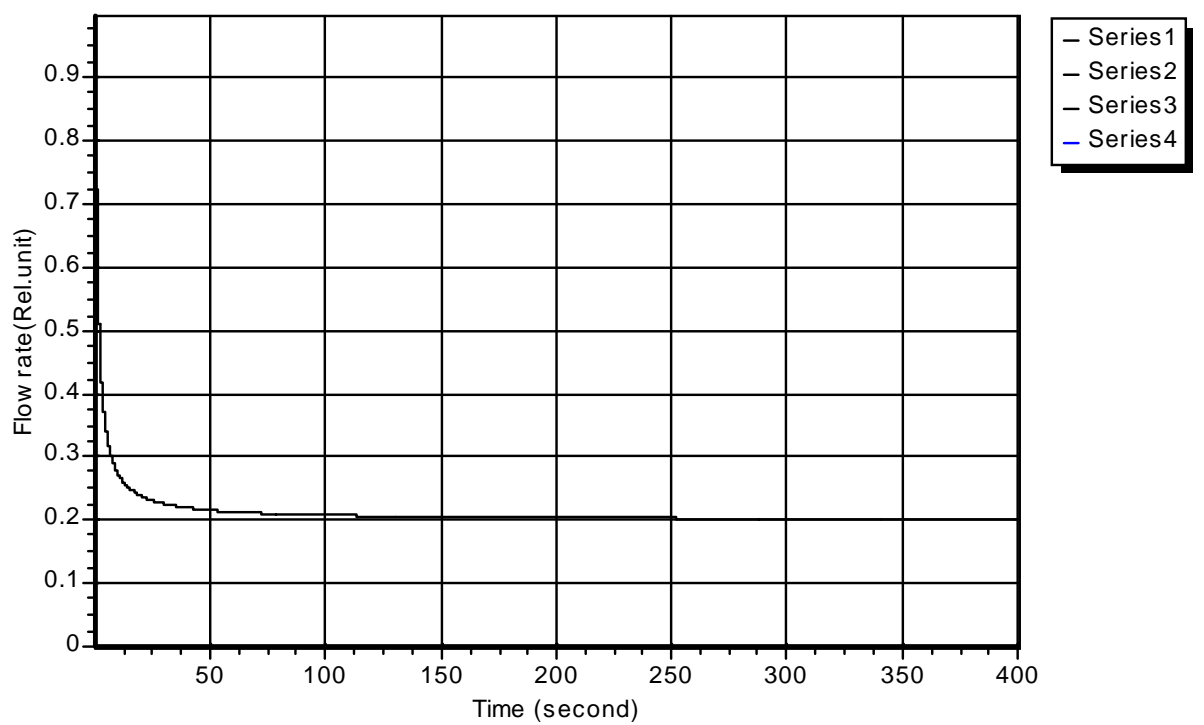

Fig. 8. The Coolant Flow Rate Change During UTOP-ULOF Accident for Nitride Fuelled Core
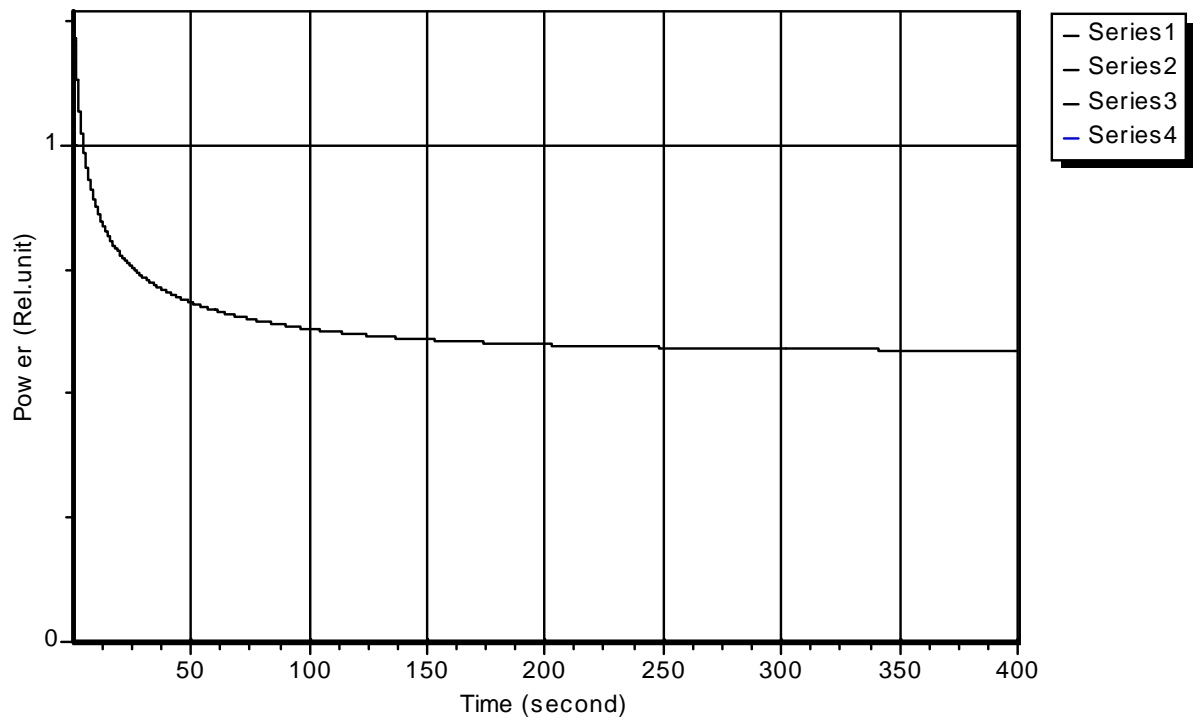

Fig. 9. The Change of Power Level with The Time for ULOF UTOP Accident with Nitride Fuelled Core 

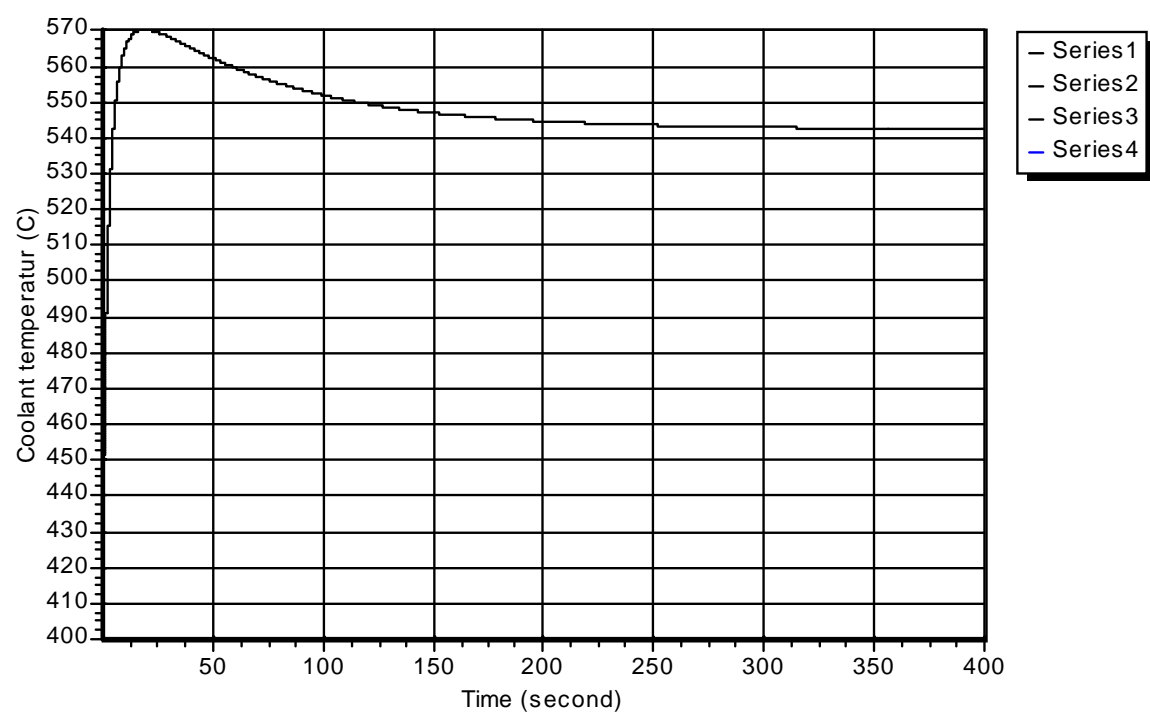

Fig. 10. The Change of Coolant Temperature with The Time for ULOF UTOP Accident with Nitride Fuelled Core

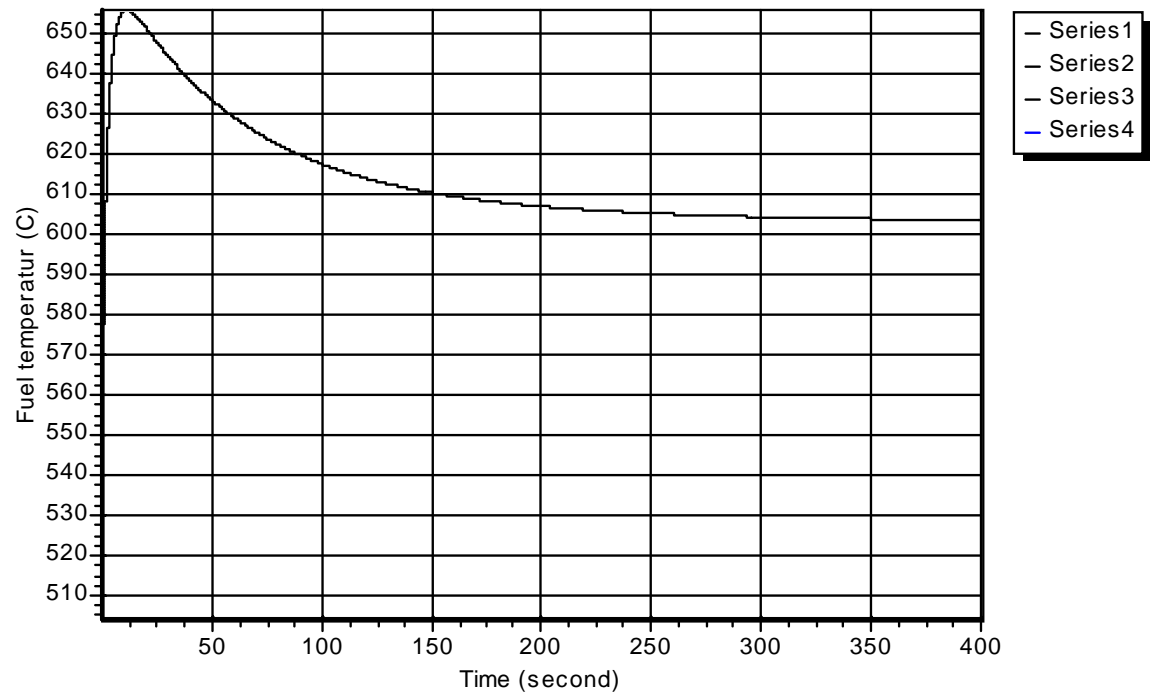

Fig 11. The Change of Fuel Temperature with The Time for ULOF UTOP Accident with Nitride Fuelled Core 


\section{Transient in Full Scale Simulation}

The full scale transient simulation in the liquid metal cooled fast reactors is described in detail at the references. The example of the results is shown as follows.

Tabel 1. Parameters for MOX FUEL 75 MWth

\begin{tabular}{|c|c|c|}
\hline Parameter & Specification & \\
\hline Reactor power & 75MWth $(\sim 30 \mathrm{MWe})$ & \\
\hline Average burnup & $\sim 10 \% \mathrm{HM}$ & \\
\hline Peak Burnup & $\sim 12 \% \mathrm{HM}$ & \\
\hline Coolant & $\mathrm{Pb}-\mathrm{Bi}$ & \\
\hline Shielding material & $\mathrm{B}_{4} \mathrm{C}+$ Stainless steel & \\
\hline Fuel material & $\mathrm{UO}_{2}-\mathrm{PuO}_{2}+$ addtional Np237 & \\
\hline Fuel enrichment & $9-13 \%$ & \\
\hline Average power density & $60 \mathrm{~W} / \mathrm{cm}^{3}$ & \\
\hline Inlet / average outlet temperature & $325^{\circ} \mathrm{C} / 450^{\circ} \mathrm{C}$ & \\
\hline \multicolumn{3}{|l|}{ Core volume fraction } \\
\hline Fuel & $\begin{array}{l}40-60 \% \text { (inner blanket), } 60 \% \\
\text { (main core) }\end{array}$ & \\
\hline Structure & $10-30 \%$ & \\
\hline Coolant & $30 \%$ & \\
\hline Core Size & $\mathrm{R}$ & Z \\
\hline Inner blanket width & $20 \mathrm{~cm}$ & $20 \mathrm{~cm}$ \\
\hline Core width & $43 \mathrm{~cm}$ & $43 \mathrm{~cm}$ \\
\hline Reflector(coolant) & $10 \mathrm{~cm}$ & $10 \mathrm{~cm}$ \\
\hline Shielding & $40 \mathrm{~cm}$ & $40 \mathrm{~cm}$ \\
\hline Reactor life time & $\begin{array}{l}35 \text { years continuously (without } \\
\text { refueling and reshuffling }\end{array}$ & \\
\hline Reactivity swing & About $1 \$$ & \\
\hline
\end{tabular}

We perform ULOF and UTOP simulation which the results are shown in Figs. 


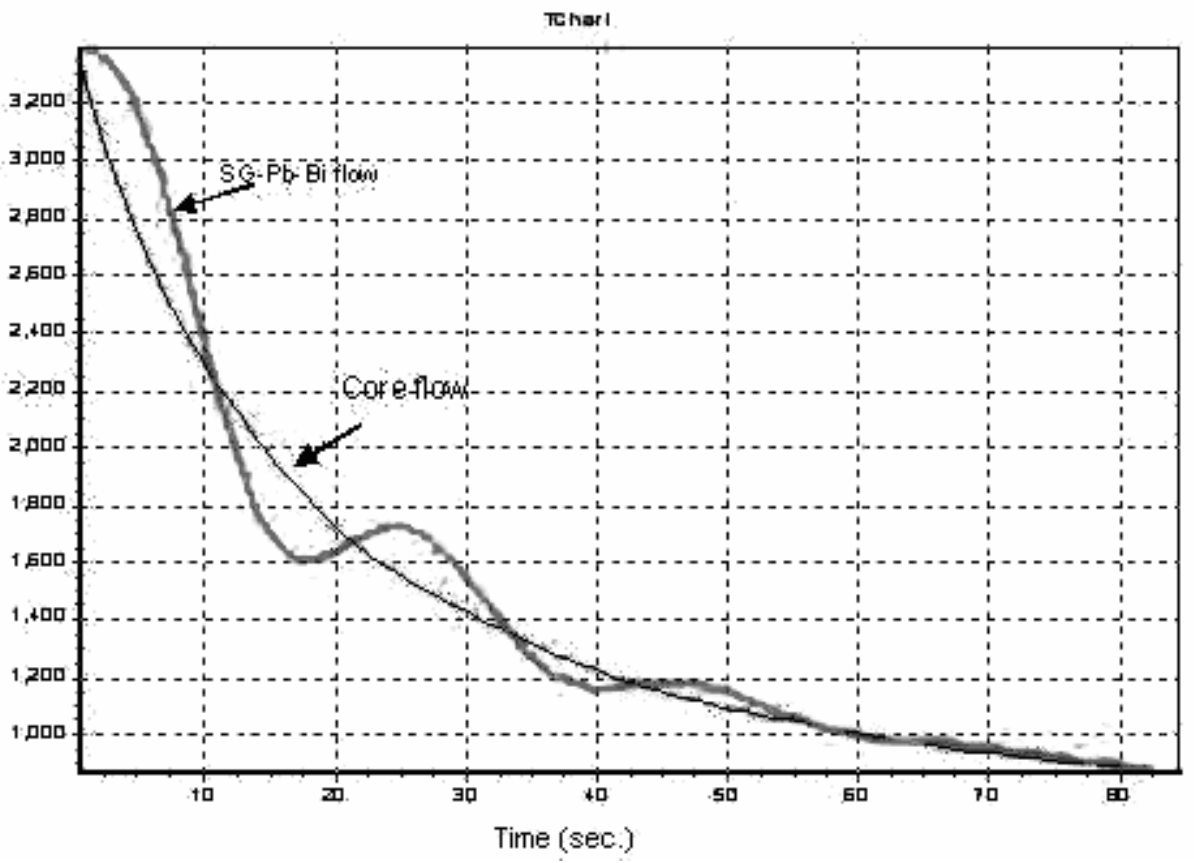

Fig. 12. The Change of Core and SG Primary Side Flow Rates with The Time for $75 \mathrm{MW}$ th MOX Fueled Pb-Bi Cooled Fast Reactors Under ULOF Accidents

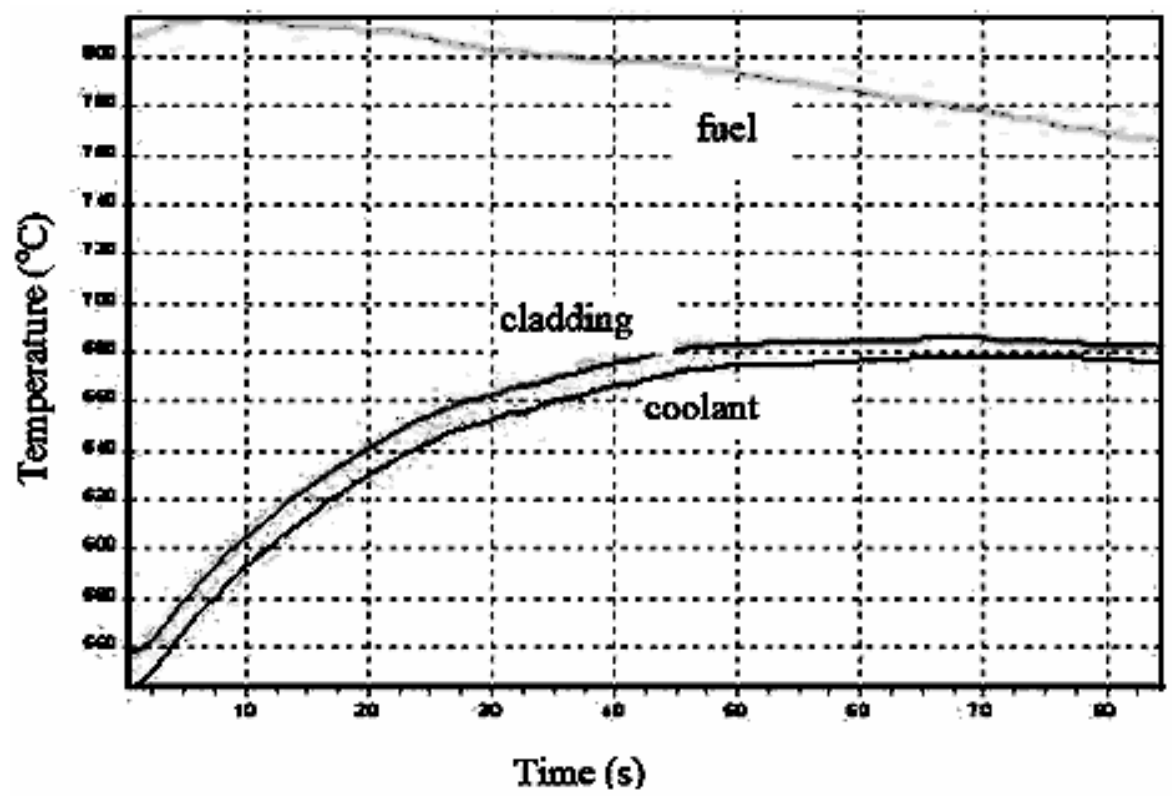

Fig.13. The Change of Hot Spot Temperature with The Time for 75 Mwth MOX Reactor During ULOF Accident 


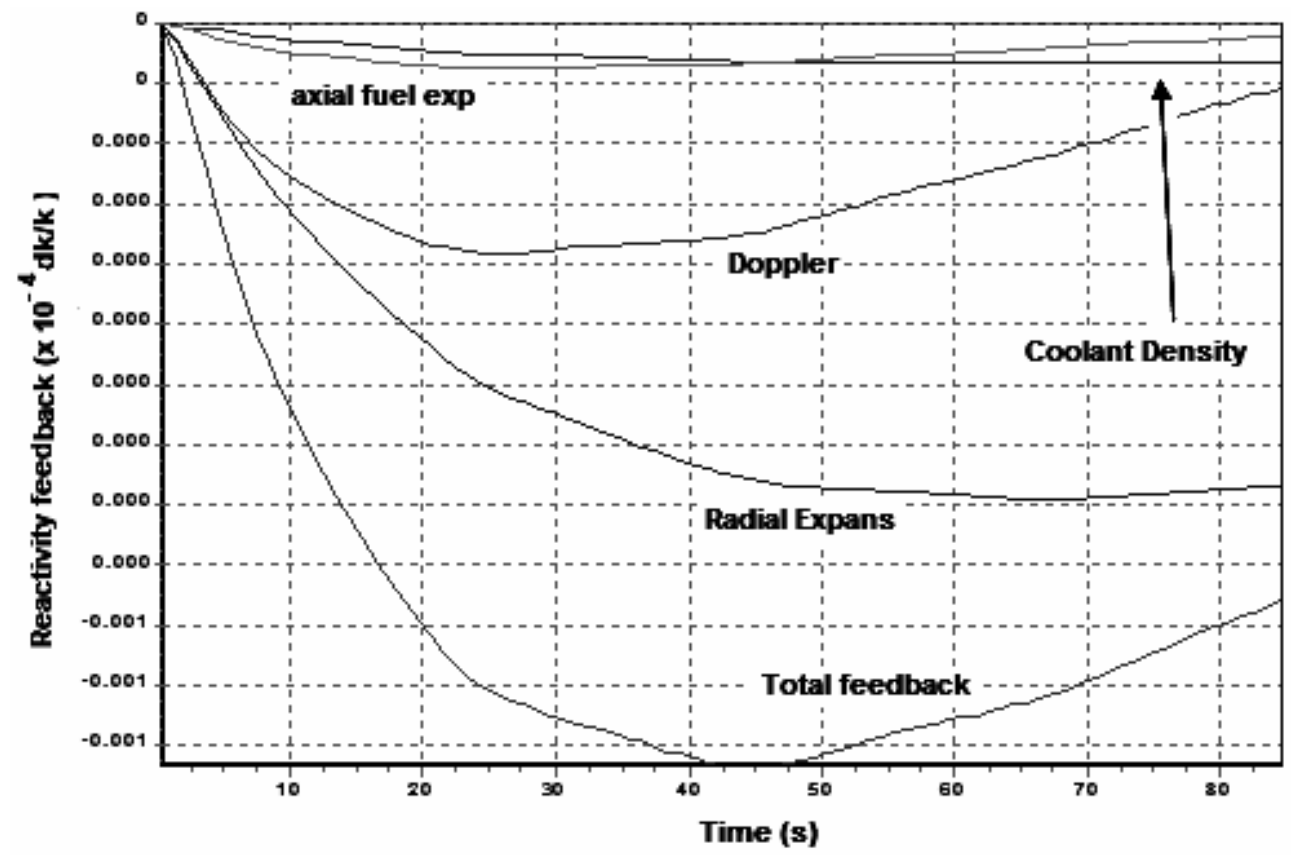

Fig. 14. The Change of Reactivity Feedback with The Time Under ULOF Accident

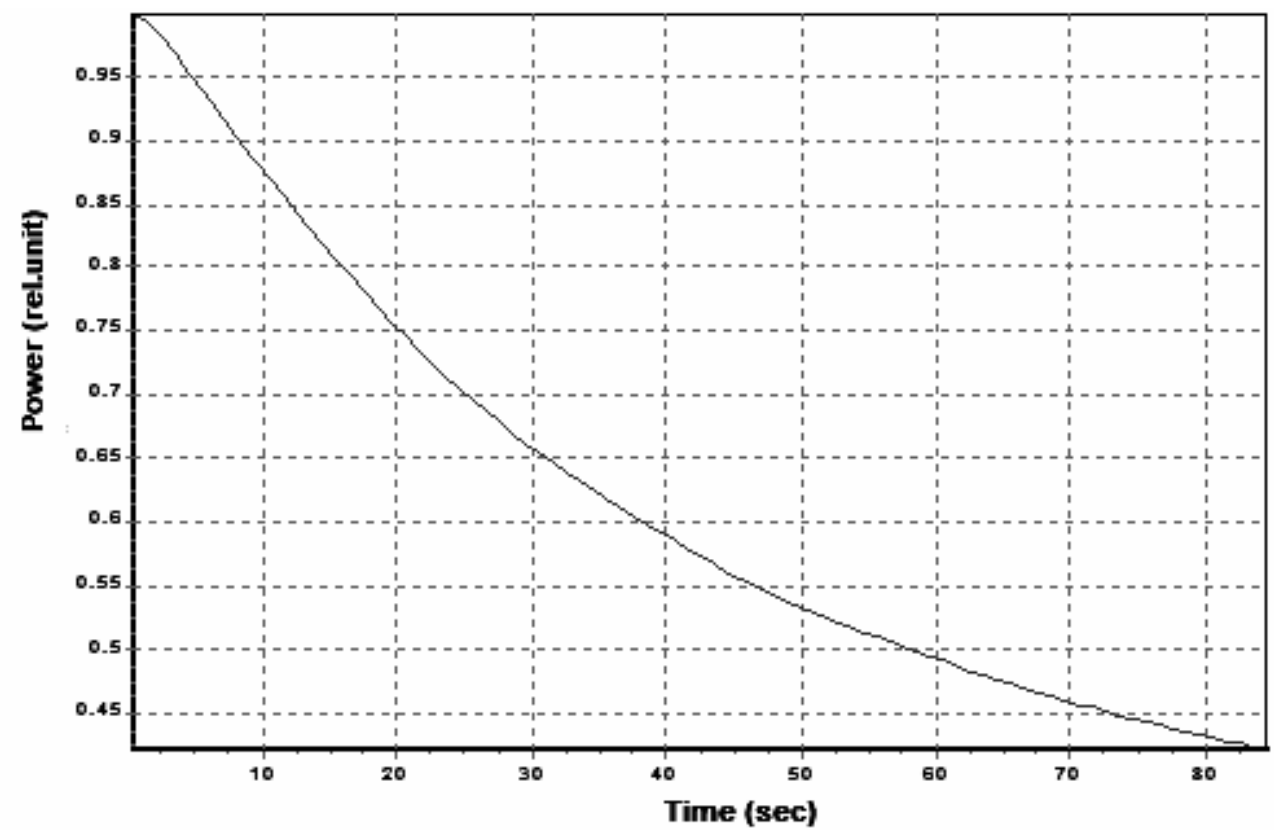

Fig. 15. The Change of Reactor Power With The Time Under ULOF Accident.

Figs. 12 to 15 show the results of the ULOF Accident. It is assumed that at $t=0$ the pump started to loss its power so that it start to coast-down. It is also assumed that 
the pump halving time is 10 seconds. Fig. 12 shows the change of coolant flow-rate during accident. It is shown that few second after the start of accident the core flowrates and SG primary flow-rate decrease significantly toward the natural circulation level. The reduction of flow-rate causes temperature increase in coolant, cladding, and fuel pellet as shown in Fig. 13.

The increase of coolant, cladding, and fuel pellet temperature in turn cause negative feedback as shown in Fig. 14. It is shown that Radial expansion and Doppler reactivity feedback are important to create negative feedback to reduce the power level so that the system can move toward new equilibrium condition.

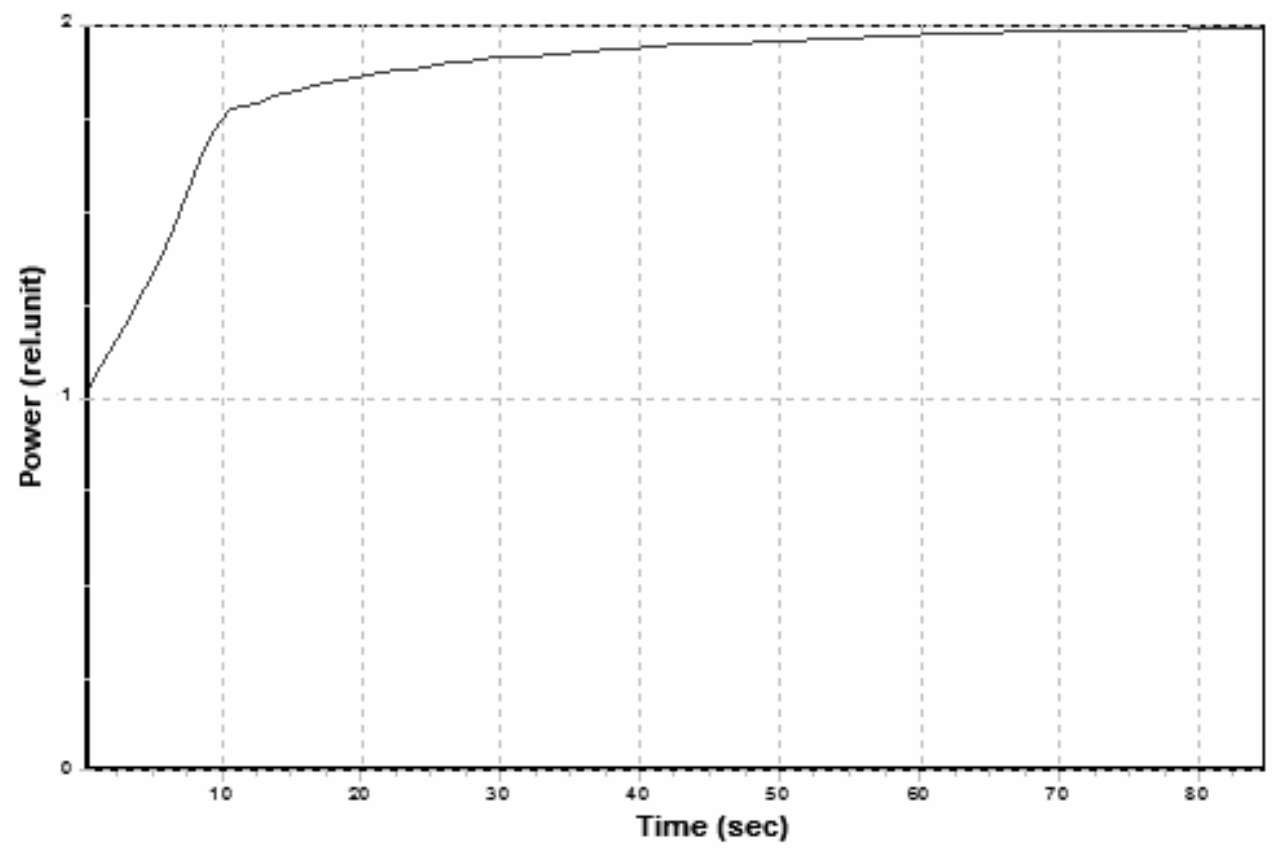

Fig. 16 The Change of Reactor Power With The Time For 75 Mwth MOX Fueled $\mathrm{Pb}-\mathrm{Bi}$ Cooled Fast Reactors Under UTOP Accident. 


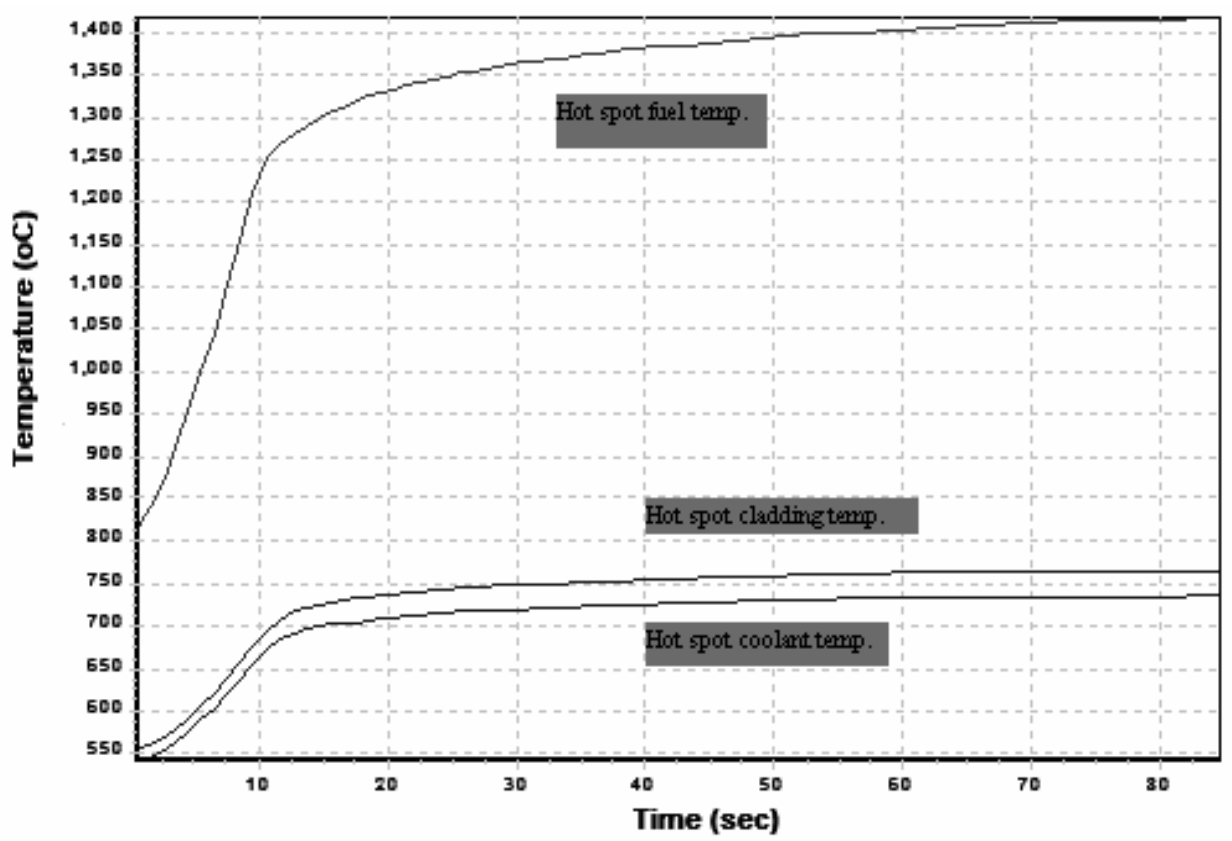

Fig. 17. The Change of Hot Spot Coolant, Cladding and Fuel Temperature During UTOP Accident

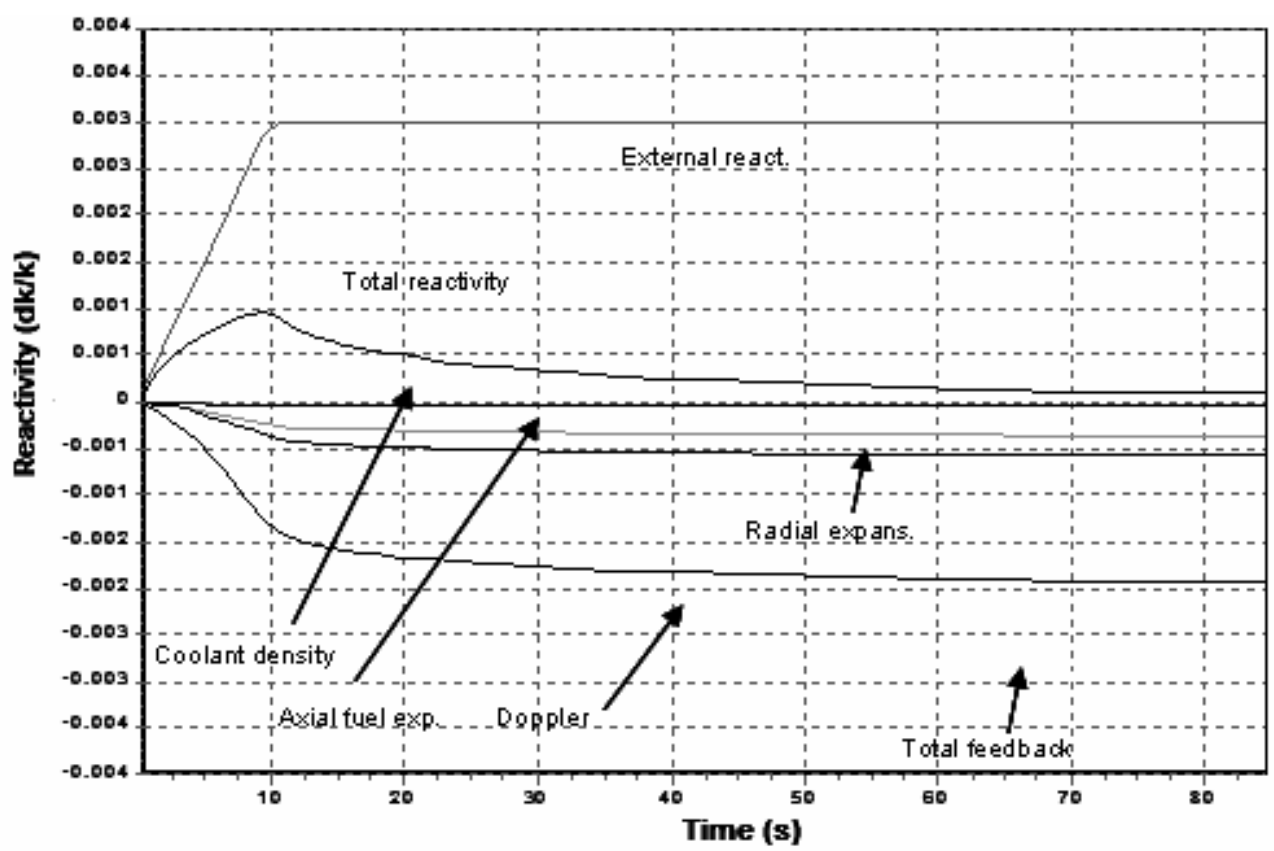

Fig. 18 The Change of Reactivity Feedback With The Time During UTOP Accident 
Figs. 16, 17 and 18 show the simulation results of UTOP accident. It is assumed that a rather large reactivity input that is $0.3 \% \mathrm{dk} / \mathrm{k}$ positive external reactivity is introduced linearly during 10 seconds. Finally the system reach new equilibrium condition with elevated power level thank to enough Doppler and Radial expansion feedback to compensate the external reactivity.

Therefore Doppler and fuel axial reactivity feedback is more importantin UTOP case than in ULOF case. It is shown that this reactor can survive $0.3 \%$ external reactivity inherently.

\section{Conclusion}

Accident analysis for liquid metal cooled fast reactors with various level of complexity/accuracy has been developed. Asymptotic model is very useful in the study of general safety performance especially the inherent safety characteristics globally. This method is useful for inherent safety introduction for undergraduate students.

The transient simulation with simplified model is useful to simulate long term behaviour of the system under a certain accident condition which need long term simulation. It is also useful for nuclear education. The full scale simulation is useful for real NPP design simulation and for master student and doctoral student research.

\section{REFERENCES}

1. BAOAN, Y., YONGWEI, Y., ZHENGPING, 1991, FRLOF-2, “A Computer Program For Fast Reactors Safety Analysis", Int. Conf. on Fast Reactor and Related Fuel Cycles, FR '91, Kyoto, p.3.1.1-3.1.8

2. CHENG, S.K., TODREAS, N.E., 1986, "Hydrodynamic Models and Correlations For Bare and Wire-Wrapped Hexagonal Rod Bundles”, Nucl. Eng. Des., 92, 227.

3. COFFIELD, R.D., MARKLEY, R.A., 1980, Natural Convection Analysis and Verification For LMFBR Cores, Nucl. Eng. Des., 62, 181-198.

4. GUPPY, J.G., 1993, “Super System Code”, NUREG/CR-3169.

5. KAKAC, S., SHAH, R.K., AUNG, W, 1987, Handbook of Single Phase Convective Heat Transfer, Wiley, 7.1-7.62.

6. NAKAGAWA, K., TSUCHIHASHI, K., 1984, SLAROM: “A Code For Cell Homogenization Calculation Of Fast Reactor", (Japan Atomic Energy Research Institute, Ibaraki), JAERI M-1294.

7. OTT, K.O., NEUHOLD, R.J, 1985, "Nuclear Reactor Dynamics”, ANS.

8. SEKIMOTO,H. AND ZAKI S, 1995, "Design study of lead and lead-bismuth cooled small long-life nuclear power reactors using metallic and nitride fuel", Nucl. Technol., 109, 307-313.

9. WALTAR, A.E., REYNOLDS, A.B, (1981), Fast Breeder Reactors, Pergamon, NewYork. 
10. ZAKI S., SEKIMOTO, H, (1996), Accident Analysis of Lead or Lead-Bistmuth Cooled Small Safe Long-Life Fast Reactor using Metallic or Nitride Fuel, J. Nucl. Eng. And Design, 162, Elsevier Science, 205-222.

11. ZAKI S, (1998), Comparative Study on Safety Performance of Nitride Fueled Lead-Bismuth Cooled Fast Reactor with Various Power Level, Prog. of Nucl. En., 32, No. 3/4, 571 577.

12. ZAKI. S., ARBI, B., SEDYARTOMO S, (2005), The Prospect of MOX Fuel Based PbBi Cooled Small Nuclear Power Reactors, Prog. of Nucl. En., 47, 212-221. 